\title{
Kranvann kan væere godt nok som rensemiddel ved sårstell
}

Vann fra krana som rensemiddel økte ikke antall infeksjoner hos voksne med akutte sår sammenlignet med saltvann. Ved stell av epiostomi-sår var det ingen forskjell mellom å rense med vann eller sprit målt i antall infeksjoner. Slik konkluderer Cochrane-samarbeidet etter å ha gått systematisk gjennom relevant forskningslitteratur.

Hensikten med å rense sår er å forebygge eller behandle sårinfeksjoner. Vann til sårstell kan være lunkent vann fra krana, destillert vann, kokt vann som er avkjølt eller saltvann. Saltvann blir ofte foretrukket, siden det antas å ikke påvirke den naturlige sårtilhelingen.

Vann til sårstell brukes også $\mathrm{i}$ Norge, men det er ulik praksis og uenighet rundt bruken av kranvann. Motstanderne av kranvann ved sårstell frykter at kranvannet kan inneholde bakterier som kan gi infeksjoner. Kvaliteten på vannet fra krana er derfor viktig.

\section{VIRKER KRANVANN BEDRE SOM RENSEMIDDEL FOR SÅR ENN SALTVANN?}

Studiene viste at:

- Kranvann senker trolig risikoen for infeksjoner hos voksne med akutte sår mer enn saltvann.

- Det er mulig at omtrent like mange barn får infeksjoner i akutte overflatesår enten de får renset såret med kranvann eller ikke.

- Omtrent like mange voksne får trolig helet kroniske sår enten de renser såret med kranvann eller ikke.

\section{VIRKER KRANVANN BEDRE SOM RENSEMIDDEL PÅ SÅR} ENN INGEN RENSING AV SÅR?

Studiene viste at:

- Kvaliteten på tilgjengelig forskning er for lav til å avgjøre om kranvann heler akutte sår hos voksne bedre enn ingen rensing av sår.

- Det er mulig at omtrent like mange voksne får infeksjon enten de får renset akutte sår med kranvann eller ikke. Det betyr at det var ingen forskjell mellom å rense akutte sår med kranvann eller ingen rensing på antall infeksjoner. Kvaliteten på denne dokumentasjonen var lav.

\section{HVA ER DENNE}

\section{INFORMASJONEN BASERT PÅ?}

Et internasjonalt forskerteam lette etter studier som undersøkte om ulike typer vann som rensemiddel ved sårstell fremmer sårtilhelingen og forebygger infeksjoner. Forskerne fant 11 studier som oppfylte kravene de hadde fastsatt på forhånd. Studiene hadde til sammen 3449 deltagere, og ble utført i Australia, Tyskland, Singapore, Sverige, USA og Tanzania. I studien fra Australia ble det bemerket at kranvannet møtte landets krav til god kvalitet. Ellers ble ikke kvaliteten på kranvannet nevnt i noen av de andre studiene.

Studiene de fant sammenlignet å bruke vann fra krana med ingen rensing, saltvann, kokt avkjølt vann eller sprit. Én studie sammenlignet destillert vann og/eller kokt avkjølt vann med saltvann.

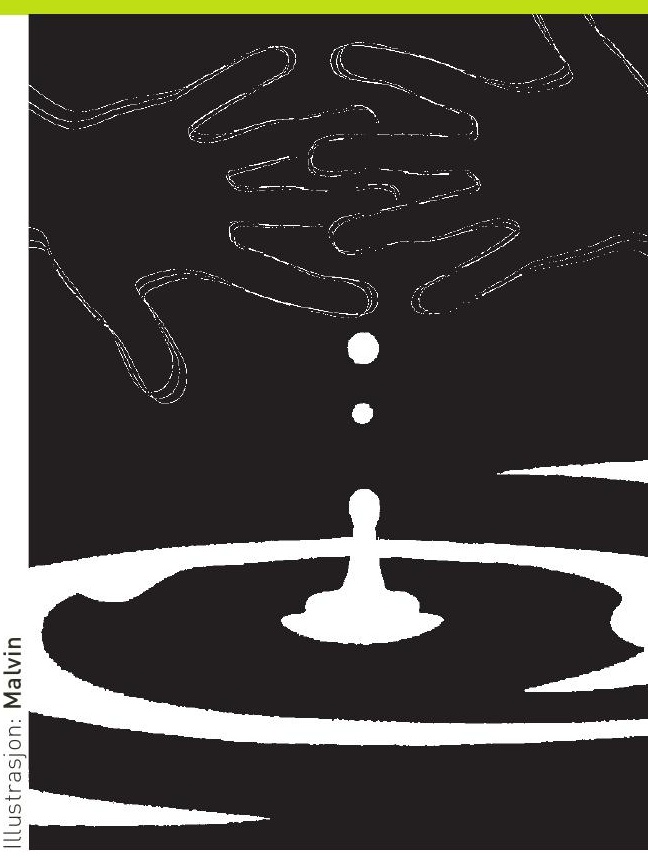

Deltagerne i studiene var i alderen 2-95 år med kroniske eller akutte sår (som enkle overflatesår eller sår etter små kirurgiske inngrep). Sårstellet ble utført på sykehus i de fleste studiene, og hjemme i én studie. Leger, sykepleiere eller pasienten selv utførte sårstellet.

\section{KILDE}

Fernandez R, Griffiths R. Water for wound cleansing. Cochrane database of Systematic Reviews 2008, Issue 1. Art. No.:CD003861. D0I:10.1002/14651858 CD003861.pub2.

Les hele artikkelen i Cochrane Library (gratis tilgang via www.cochrane.no) eller prøv denne direkte lenka: http://www. mrw.interscience.wiley.com/cochrane/ clsysrev/articles/CD003861/frame.html

Skrevet av Hilde Tinderholt Myrhaug, Nasjonalt kunnskapssenter for helsetjenesten 